\title{
SURVEI KOMPETENSI PEDAGOGIK GURU SEKOLAH DASAR (SD) DALAM MENDUKUNG IMPLEMENTASI KURIKULUM 2013 DI KABUPATEN KETAPANG
}

\author{
Norsidi \\ Program Studi Pendidikan Geografi \\ Fakultas Ilmu Pendidikan dan Pengetahuan Sosial IKIP PGRI Pontianak \\ Jalan Ampera Nomor 88 Pontianak - 78116, Telepon (0561) 748219 Fax. (0561) 589855 \\ Alamat e-mail: habibisukma1991@gmail.com
}

\begin{abstract}
Abstrak
Penelitian ini bertujuan untuk mengetahui kemampuan pedagogik guru Sekolah Dasar (SD) dalam mendukung implementasi kurikulum 2013 di Kabupaten Ketapang. Metode yang digunakan dalam penelitian ini adalah kuantitatif deskriptif. Data yang digunakan berupa data primer yang dikumpulkan melalui angket. Analisis data menggunakan rata-rata dan persentase skor. Hasil penelitian ini menunjukkan kemampuan pedagogik pada yang meliputi: a) memahami karateristik peserta didik dari aspek fisik, moral, spiritual, sosial, kultural emosional, dan intelektual dikategorikan baik; b) menguasai Teori Belajar dan Prinsip-Prinsip Pembelajaran dikategorikan baik; c) mengembangkan kurikulum terkait mata pelajaran yang diampu dikategorikan baik; d) menyelenggarakan pembelajaran yang mendidik dikategorikan baik; e) memanfaatkan teknologi informasi dan komunikasi dikategorikan kurang mampu; f) mengembangkan peserta didik untuk mengaktualisasikan berbagai potensi yang dimilikinya dikategorikan baik; g) berkomunikasi secara efektif, empatik, dan santun dikategorikan baik; h) menyelenggarakan penilaian dan evaluasi proses hasil belajar; i) Memanfaatkan hasil penilaian dan evaluasi dikategorikan baik; j) Melakukan tindakan reflektif dikategorikan baik.
\end{abstract}

Kata Kunci: Kompetensi Pedagogik, Kurikulum 2013, Ketapang

\begin{abstract}
This study aims to determine pedagogical skills of elementary school teachers in support of the implementation of the 2013 curriculum in Ketapang District. The method used in this research is quantitative descriptive. The data used are primary data collected through questionnaire. Data analysis uses averages and percentage of scores. The results of this study indicate pedagogic ability in which include: a) understanding the characteristics of learners from the physical, moral, spiritual, social, cultural, emotional, and intellectual aspects are categorized as good; b) Mastering Learning Theory and Learning Principles are categorized as good; c) developing curriculum related subjects that are categorized well; d) conducting educational learning is categorized as good; e) utilizing information and communication technology categorized as less capable; f) developing learners to actualize their potentials well categorized; g) communicate effectively, empathically, and well-categorized; $h$ ) conduct assessment and evaluation of learning outcomes; i) Make use of assessment and evaluation results categorized as good; j) Taking reflective action is categorized well.
\end{abstract}

Keywords: Pedagogic Competency, Curriculum 2013, Ketapang

\section{PENDAHULUAN}


Kurikulum merupakan pondasi untuk mengatur pelaksanaan proses kegiatan belajar mengajar dalam pelaksanaan sistem pendidikan yang ada di Inondesia. Undang-Undang Nomor 20 Tahun 2003 tentang Sistem Pendidikan Nasional menyebutkan bahwa kurikulum adalah seperangkat rencana dan pengaturan mengenai tujuan, isi, dan bahan pelajaran serta cara yang digunakan sebagai pedoman penyelenggaraan kegiatan pembelajaran untuk mencapai tujuan pendidikan tertentu.

Konsep kurikulum 2013 yang dibuat oleh para ahli pendidikan yang ada di Indonesia sengaja untuk mempersiapkan dan membentuk kualitas sumberdaya manusia yang memiliki kemampuan hidup, baik sebagai insan pribadi yang cendekia, taat beragama, produktif, aktif, Inovatif dan berkreativitas tinggi serta mampu bersaing dan memberikan kontribusi pada kehidupan bermasyarakat, berbangsa, bernegara, dan pada peradaban dunia. Pengembangan kurikulum 2013 dilakukan karena adanya tantangan internal maupun tantangan eksternal (Kemendikbud 2013a).

Bila kurikulum tidak diubah, lulusan yang dihasilkan adalah lulusan usang yang tidak terserap di dunia kerja (Kemendikbud 2012). Mulyasa (2013) menjelaskan bahwa meskipun diterapkan secara bertahap, kurikulum 2013 ini berdampak pada berbagai upaya persiapan yang harus dilakukan berbagai pihak, antara lain tersusun dan disahkannya naskah penyempurnaan Kurikulum yang utuh, sosialisasi naskah kurikulum yang sudah disahkan, kesiapan dinas pendidikan daerah menyongsong kurikulum 2013, kesiapan kepala sekolah dalam mengelola penyelenggaraan pendidikan dalam satuan pendidikan, kesiapan guru mata pelajaran dalam melaksanakan pembelajaran yang mendidik, kesiapan guru bimbingan dan konseling yang memandirikan, kesiapan Lembaga Pendidikan Tenaga Kependidikan (LPTK) menyiapkan lulusan siap melaksanakan tugas Kurikulum 2013.

Berdasarkan observasi awal yang dilakukan oleh peneliti masih banyak terdapat para guru sekolah dasar (SD) khususnya yang ada di Kabupaten Ketapang belum mampu dan memahami dalam mengimplementasikan Kurikulum 2013 dalam sebuah mata pelajaran. Data dari Dinas Pendidikan Kabupaten 
Ketapang mengenai Sekolah Dasar (SD) yang sudah menerapkan Kurikulum 2013 sebanyak $20 \%$ yang hanya diperuntukkan bagi sekolah yang telah mendapatkan nilai akreditasi sekolah dengan bobot A saja. Untuk Sekolah Dasar (SD) yang belum menerapkan Kurikulum 2013 sebanyak 80\%. Hal ini membuktikan bahwa terdapat banyak Sekolah Dasar yang masih belum memiliki kemampuan untuk menerapkan Kurikulum 2013. Guru adalah pemeran utama dalam proses peningkatan kualitas pembangunan pendidikan, khususnya pendidikan formal (Muhamad, Amram, \& H. Asep, 2016). Kondisi tersebut harus menjadi perhatian pemerintah daerah Kabupaten Ketapang.

Kurikulum 2013 merupakan kurikulum yang baru diterapkan oleh para guru sekolah dasar (SD) dalam pelaksanaan pembelajaran yang ada di Kabupaten Ketapang. Hal ini tentunya, butuh penyesuaian dan persiapan yang matang untuk menghadapi berbagai persoalan dan tantangan dalam implementasinya. Selain itu juga buku pelajaran berbasis K-13 yang tersedia sangat terbatas menyebabkan terhambatnya penerapan K-13 pada siswa sehingga seluruh guru hanya mengandalkan silabus yang dirancang dan diberikan oleh pemerintah melalui Kementerian Pendidikan. Permasalahan ini merupakan kritikan yang harus menjadi masukan dan perhatian bagi pemerintah daerah Kabupaten Ketapang dalam penyelesaian permasalahan pendidikan terutama dalam meningkatkan kemampuan guru.

Kurikulum 2013 ini menuntut para guru untuk melaksanakan kegiatan pembelajaran berbasis tematik integrative dan pendekatan sains. Muatan kurikulum 2013 Guru juga harus menguasai dan memiliki empat kompetensi dalam mengajar yaitu kompetensi profesional, pedagogik, sosial dan kepribadian. Keempat kompetensi tersebut, merupakan kunci keberhasilan dalam menyelenggarakan pendidikan (Fitri, 2015). Melaksanakan Kurikulum 2013 guru perlu mendalami kompetensi pedagogik karena berkaitan dengan pengembangan kurikulum yang secara berkelanjutan dalam proses pembelajaran. Seorang guru sangat berbeda dengan ilmuwan, bukan saja harus memiliki kualitas atau kuantitas pengetahuan materi tetapi seorang guru harus dapat memiliki pengetahuan bagaimana mengorganisir pengetahuan materinya dapat digunakan dengan baik 
(Neneng, 2014). Kompetensi pedagogik menyangkut proses implementatif pendidikan dengan menggunakan berbagai strategi untuk mengembangkan potensi peserta didik secara optimal, sebagai tujuan utama dari penyelenggaraan kegiatan pendidikan (Nani, 2015).

\section{METODE}

Metode yang digunakan dalam penelitian ini adalah kuantitatif deskriptif yaitu menggunakan perhitungan-perhitungan angka untuk menganalisis kemampuan pedagogik guru dalam implementasi kurikulum 2013. Penelitian ini populasinya adalah seluruh guru SD kelas I, II, IV dan V di Kabupaten Ketapang yang menerapkan Kurikulum 2013. Teknik pengambilan sampel yang digunakan dalam penelitian ini menggunakan purposive sampling yang artinya sampel dipilih berdasarkan pada ciri atau karakteristik dan pertimbangan-pertimbangan berdasarkan tujuan penelitian sebagaimana yang diungkapkan oleh Dantes (2012:46). Sampel yang dipilih berdasarkan pertimbangan tertentu yang diambil itu berdasarkan tujuan penelitian ini, yaitu untuk mengukur kemampuan pedagogik guru dalam implementasi kurikulum 2013 yang dilaksanakan di sekolah dasar Kabupaten Ketapang. Data yang digunakan berupa data primer dikumpulkan melalui angket. Analisis data menggunakan rata-rata dan persentase skor. Sebagian besar informasi hasil dari penelitian akan dituangkan melalui perwujudan dalam bentuk angka-angka.

\section{HASIL PENELITIAN DAN PEMBAHASAN}

\section{A. Memahami Karateristik Peserta Didik dari Aspek Fisik, Moral, Spiritual, Sosial, Kultural Emosional, dan Intelektual}

Indikator mengenai pemahaman karakteristik peserta didik dari aspek fisik, moral, spiritual, sosial, kultural emosional, dan intelektual sebagai berikut:

Tabel 1. Statistik deskriptif indikator 1

\begin{tabular}{|c|c|c|c|c|}
\hline Indikator & Mean & SD & Min & Max \\
\hline PA & 3.06 & 0.41 & 1.71 & 4 \\
\hline
\end{tabular}


Pada tabel 1 diperoleh rata-rata nilai 3.06 dengan standar deviasi 0.41. Besarnya kemampuan digambarkan sebagai berikut:

Gambar 1. Diagram kemampuan guru pada indikator 1

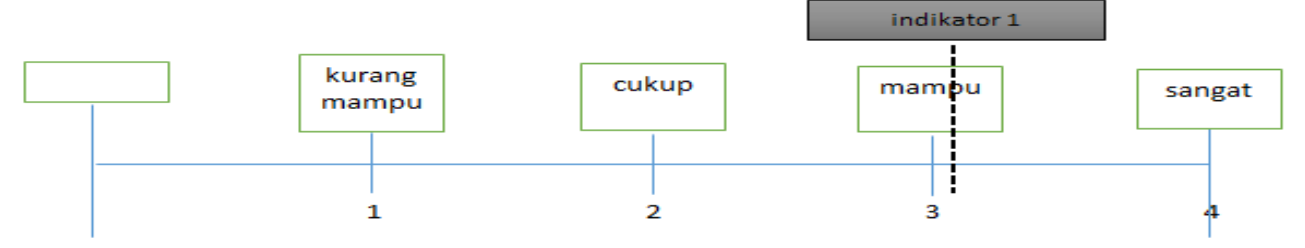

Tabel 2. Distribusi Frekuensi Pada Indikator 2

\begin{tabular}{|c|l|r|r|}
\hline No & \multicolumn{1}{|c|}{ Kategori } & Frekuensi & Persentase \\
\hline 1 & Tidak paham/tidak sesuai & 15 & 0.4 \\
2 & Kurang paham/kurang sesuai & 511 & 14.9 \\
3 & Paham/sesuai & 2254 & 65.5 \\
4 & Sangat paham/sangat sesuai & 660 & 19.2 \\
\hline \multicolumn{2}{|c|}{ Total } & 3440 & 100 \\
\hline
\end{tabular}

Hasil intepretasi data responden menjawab tidak paham/tidak sesuai sebanyak (19,1\%), yang menjawab kurang paham/kurang sesuai (282,1\%), menjawab paham/sesuai sebanyak (1635,6\%), dan menjawab sangat paham/sangat sesuai sebanyak $(472,1 \%)$ dikategorikan baik.

\section{B. Menguasai Teori Belajar dan Prinsip-Prinsip Pembelajaran}

Hasil penelitian untuk indikator kedua mengenai penguasaan teori belajar dan prinsip pembelajaran dengan hasil sebagai berikut:

Tabel 3. Statistik deskriptif indikator 2

\begin{tabular}{|c|c|c|c|c|}
\hline Indikator & Mean & SD & Min & Max \\
\hline PB & 3.035 & 0.432 & 2 & 4 \\
\hline
\end{tabular}

Pada tabel 3 diperoleh rata-rata nilai 3.035 dengan standar deviasi 0.432.Besarnyakemampuan digambarkan sebagai berikut: 
Gambar 2. Diagram kemampuan guru pada indikator

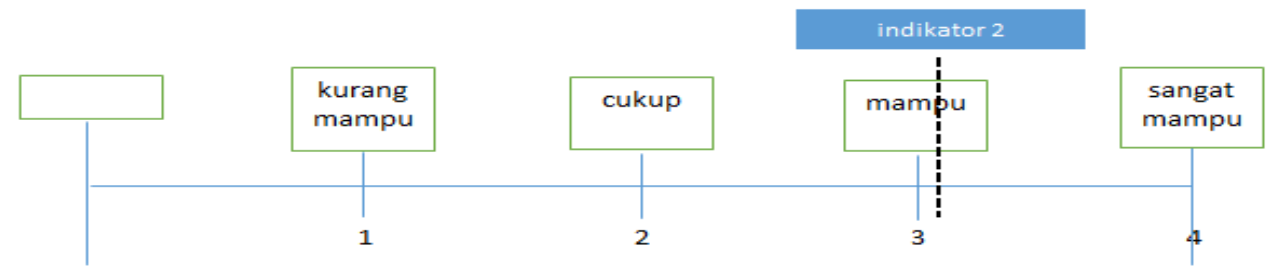

Tabel 4. Distribusi Frekuensi Pada Indikator 2

\begin{tabular}{|c|l|r|r|}
\hline No & \multicolumn{1}{|c|}{ Kategori } & Frekuensi & Persentase \\
\hline 1 & Tidak paham/tidak sesuai & 15 & 0.4 \\
2 & Kurang paham/kurang sesuai & 511 & 14.9 \\
3 & Paham/sesuai & 2254 & 65.5 \\
4 & Sangat paham/sangat sesuai & 660 & 19.2 \\
\hline \multicolumn{2}{|c|}{ Total } & 3440 & 100 \\
\hline
\end{tabular}

Hasil intepretasi data menjawab tidak paham/tidak sesuai sebanyak $(0.4 \%)$, menjawab kurang paham/kurang sesuai sebanyak (14.9\%), untuk menjawab paham/sesuai sebanyak (65.5\%), dan yang menjawab sangat paham/sangat sesuai sebanyak (19.2\%). Hal tersebut menunjukkan bahwa dikategorikan baik.

\section{Mengembangkan KurikulumTerkait Mata Pelajaran yang Diampu}

Hasil penelitian indikator mengenai pengembangan kurikulum terkait mata pelajaran yang diampu sebagai berikut:

Tabel 5. Statistik deskriptif indikator 3

\begin{tabular}{|c|c|c|c|c|}
\hline Indikator & Mean & SD & Min & Max \\
\hline PC & 2.834 & 0.484 & 1.77 & 5.31 \\
\hline
\end{tabular}

Pada tabel 5 rata-rata nilai 2.834 dengan standar deviasi sebesar 0.484 . Besarnya kemampuan digambarkan sebagai berikut:

Gambar 3. Diagram kemampuan guru pada indikator 3

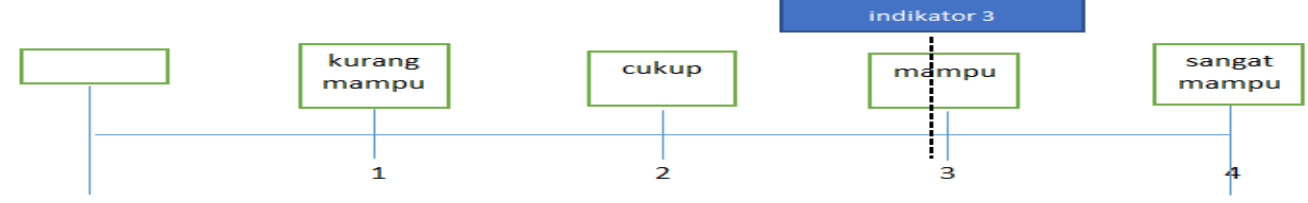


Tabel 6. Distribusi Frekuensi Pada Indikator 3

\begin{tabular}{|c|l|r|r|}
\hline No & \multicolumn{1}{|c|}{ Kategori } & Frekuensi & Persentase \\
\hline 1 & Tidak paham/tidak sesuai & 85 & 1.9 \\
2 & Kurang paham/kurang sesuai & 1212 & 27.1 \\
3 & Paham/sesuai & 2565 & 57.4 \\
4 & Sangat paham/sangat sesuai & 609 & 13.6 \\
\hline \multicolumn{2}{|c|}{ Total } & 4471 & 100 \\
\hline
\end{tabular}

Hasil intepretasi data menjawab tidak paham/tidak sesuai sebanyak (1.9\%), menjawab kurang paham/kurang sesuai sebanyak (27.1\%), menjawab paham/sesuai sebanyak (57.4\%), dan menjawab sangat paham/sangat sesuai sebanyak (13.6\%) yang dikategorikan baik.

\section{Menyelenggarakan Pembelajaran yang Mendidik}

Hasil penelitian untuk indikator mengenai menyelenggarakan pembelajaran yang mendidik sebagai berikut:

Tabel 7. Statistik deskriptif indikator 4

\begin{tabular}{|c|c|c|c|c|}
\hline Indikator & Mean & SD & Min & Max \\
\hline PD & 2.908 & 0.494 & 1.7 & 5.6 \\
\hline
\end{tabular}

Pada tabel 7 diperoleh rata-rata nilai 2.908 dengan standar deviasi 0.494. Besarnya kemampuan digambarkan sebagai berikut:

Gambar 4. Diagram Kemampuan guru indikator 4

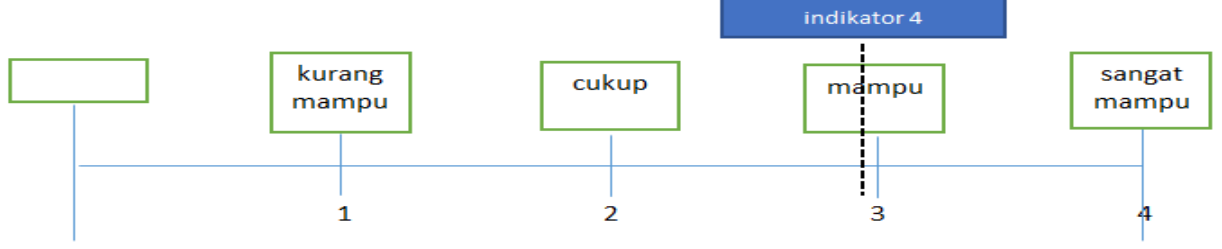

Tabel 8. Distribusi frekuensi pada indikator 4

\begin{tabular}{|c|c|r|r|}
\hline No & \multicolumn{1}{|c|}{ Kategori } & Frekuensi & Persentase \\
\hline 1 & Tidak paham/tidak sesuai & 94 & 2.7 \\
\hline
\end{tabular}




\begin{tabular}{|r|l|r|r|}
2 & Kurang paham/kurang sesuai & 746 & 21.7 \\
3 & Paham/sesuai & 2068 & 60.2 \\
4 & Sangat paham/sangat sesuai & 529 & 15.4 \\
\hline \multicolumn{2}{|c|}{ Total } & 3437 & 100 \\
\hline
\end{tabular}

Hasil intepretasi data responden menjawab tidak paham/tidak sesuai sebanyak (2.7\%), menjawab kurang paham/kurang sesuai sebanyak (21.7\%), menjawab paham/sesuai sebanyak (60.2\%), dan menjawab sangat paham/sangat sesuai sebanyak (15.4\%). Hal tersebut menunjukkan bahwa dikategorikan baik.

\section{E. Memanfaatkan Teknologi Informasi dan Komunikasi}

Hasil perhitungan indikator mengenai memanfaatkan teknologi informasi dan komunikasi sebagai berikut

Tabel 9. Statistik deskriptif indikator 5

\begin{tabular}{|c|r|r|c|c|}
\hline Indikator & Mean & SD & Min & Max \\
\hline PE & 2.233 & 0.684 & 1 & 3.8 \\
\hline
\end{tabular}

Pada tabel 9 diperoleh rata-rata nilai 2.233 dengan standar deviasi 0.684. Besarnya kemampuan digambarkan sebagai berikut:

Gambar 5. Diagram kemampuan Pedagogik indikator 5

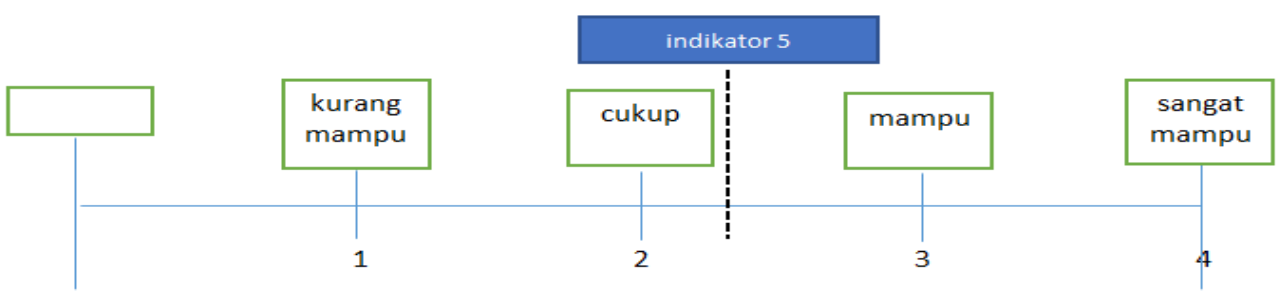

Tabel 10. Distribusi Frekuensi Pada Indikator 5

\begin{tabular}{|c|l|r|r|}
\hline No & \multicolumn{1}{|c|}{ Kategori } & Frekuensi & Persentase \\
\hline 1 & Tidak paham/tidak sesuai & 380 & 22.1 \\
2 & kurang paham/kurang sesuai & 634 & 36.9 \\
3 & paham/sesuai & 632 & 36.7 \\
4 & sangat paham/sangat sesuai & 74 & 4.3 \\
\hline & total & 1720 & 100 \\
\hline
\end{tabular}


Hasil intepretasi data menjawab tidak paham/tidak sesuai sebanyak (380,22\%), menjawab kurang paham/kurang sesuai sebanyak (634,37\%), menjawab paham/sesuai sebanyak (632,3\%), dan menjawab sangat paham/sangat sesuai sebanyak $(74,4 \%)$.dikategorikan cukup.

\section{F. Memfasilitasi Pengembangan Potensi Peserta Didik}

Hasil penelitian dari aspek yang mengenai memfasilitasi pengembangan potensi peserta didik sebagai berikut:

Tabel 11. Statistik deskriptif indikator 6

\begin{tabular}{|c|c|c|c|c|}
\hline Indikator & Mean & SD & Min & Max \\
\hline PF & 2.872 & 0.409 & 1.5 & 3.9 \\
\hline
\end{tabular}

Pada Tabel 11. diperoleh rata-rata nilai 2.872 dengan standar deviasi 0.409. Besarnya kemampuan digambarkan sebagai berikut:

Gambar 6. Diagram kemampuan guru pada indikator 6

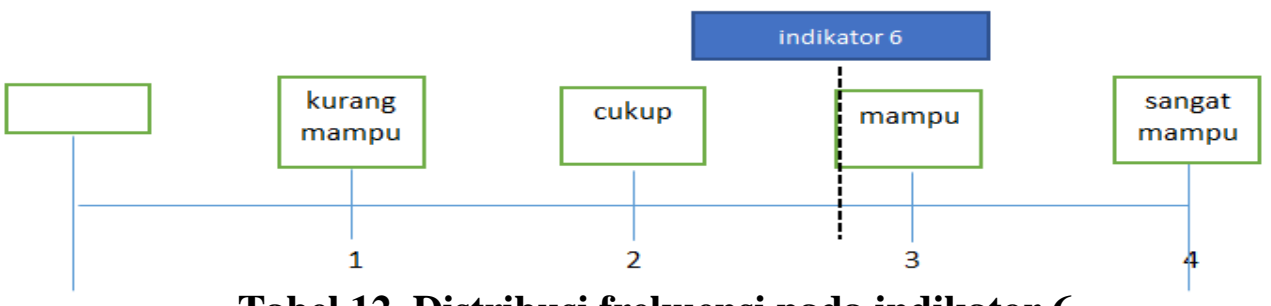

Tabel 12. Distribusi frekuensi pada indikator 6

\begin{tabular}{|c|l|r|r|}
\hline No & \multicolumn{1}{|c|}{ Kategori } & \multicolumn{1}{|c|}{ Frekuensi } & Persentase \\
\hline 1 & Tidak paham/tidak sesuai & 89 & 2.6 \\
2 & Kurang paham/kurang sesuai & 684 & 19.9 \\
3 & Paham/sesuai & 2246 & 65.3 \\
4 & Sangat paham/sangat sesuai & 421 & 12.2 \\
\hline \multicolumn{2}{|c|}{ Total } & 3440 & 100 \\
\hline
\end{tabular}

Hasil intepretasi data responden menjawab tidak paham/tidak sesuai sebanyak (2.6\%), untuk menjawab kurang paham/kurang sesuai sebanyak (19.9\%), untuk menjawab paham/sesuai sebanyak (65.3\%), dan yang menjawab 
sangat paham/sangat sesuai sebanyak (12.2\%). Hal tersebut menunjukkan bahwa dikategorikan baik.

\section{G. Berkomunikasi Secara Efektif, Empatik, dan Santun}

Hasil penelitian dari aspek mengenai berkomunikasi secara efektif, empatik, dan santun sebagai berikut:

Tabel 13. Statistik deskriptif indikator 7

\begin{tabular}{|c|c|c|c|c|}
\hline Indikator & Mean & SD & Min & Max \\
\hline PG & 3.101 & 0.453 & 1.9 & 4 \\
\hline
\end{tabular}

Pada Tabel 13 diperoleh rata-rata sebesar 3.101 dengan standar deviasi sebesar 0.453. Berikut gambar diagram kemampuan guru:

\section{Gambar 7. Diagram kemampuan guru pada indikator 7}

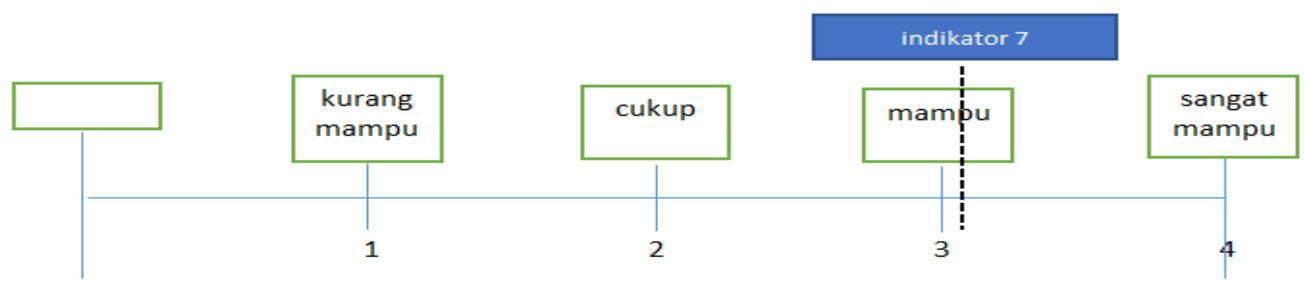

Tabel 14. Distribusi frekuensi pada indikator 7

\begin{tabular}{|c|l|r|r|}
\hline No & \multicolumn{1}{|c|}{ Kategori } & Frekuensi & Persentase \\
\hline 1 & Tidak paham/tidak sesuai & 11 & 0.3 \\
2 & Kurang paham/kurang sesuai & 389 & 11.3 \\
3 & Paham/sesuai & 2280 & 66.3 \\
4 & Sangat paham/sangat sesuai & 760 & 22.1 \\
\hline \multicolumn{2}{|c|}{ Total } & 3440 & 100 \\
\hline
\end{tabular}

Hasil intepretasi data responden menjawab tidak paham/tidak sesuai sebanyak (0.3\%), untuk menjawab kurang paham/kurang sesuai sebanyak (11.3\%), untuk menjawab paham/sesuai sebanyak (66.3\%), dan yang menjawab sangat paham/sangat sesuai sebanyak (22.1\%).Hasil penelitian menunjukkan bahwa dikategorikan baik.

\section{H. Menyelenggarakan Penilaian dan Evaluasi Proses Hasil Belajar}


Hasil penelitian mengenai kemampuan guru menyelenggarakan penilaian dan evaluasi proses hasil belajar sebagai berikut:

Tabel 15. Statistik deskriptif indikator 8

\begin{tabular}{|c|r|r|r|r|}
\hline Indikator & \multicolumn{1}{|c|}{ Mean } & \multicolumn{1}{|c|}{ SD } & \multicolumn{1}{|c|}{ Min } & Max \\
\hline PH & 3.142 & 0.548 & 2 & 4 \\
\hline
\end{tabular}

Pada tabel 15 diperoleh rata-ratanilai 3.142 dengan standar deviasiratarata 0.548. Berikut diagram gambar kemampuan guru:

Gambar 8. Diagram kemampuan guru pada indikator 8

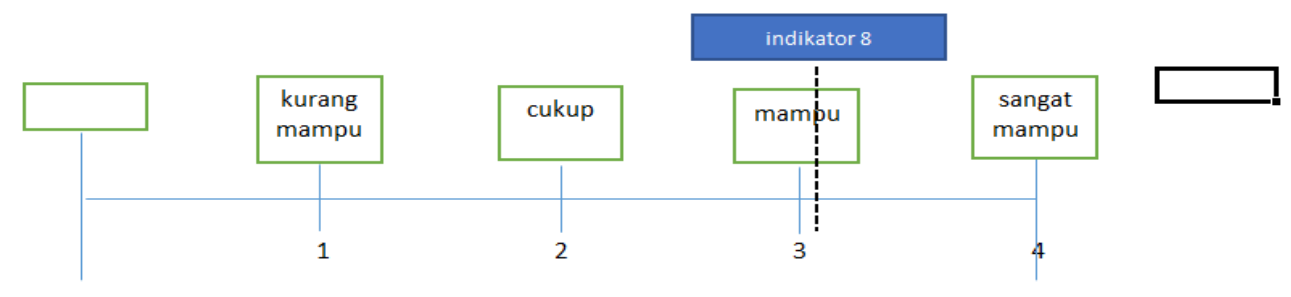

Tabel 16. Distribusi frekuensi pada indikator 8

\begin{tabular}{|c|l|r|r|}
\hline No & \multicolumn{1}{|c|}{ Kategori } & Frekuensi & Persentase \\
\hline 1 & tidak paham/tidak sesuai & 1 & 0.1 \\
2 & kurang paham/kurang sesuai & 180 & 13.1 \\
3 & paham/sesuai & 818 & 59.4 \\
4 & sangat paham/sangat sesuai & 377 & 27.4 \\
\hline \multicolumn{2}{|c|}{ Total } & 1376 & 100 \\
\hline
\end{tabular}

Hasil intepretasi data responden menjawab tidak paham/tidak sesuai sebanyak $(0.1 \%)$, yang menjawab kurang paham/kurang sesuai sebanyak (13.1\%) dan menjawab paham/sesuai sebanyak (59.4\%).Hasil tersebut menunjukkan bahwa dikategorikan baik.

\section{Memanfaatkan Hasil Penilaian dan Evaluasi}

Hasil penelitian untuk indikator mengenai pemanfaatan hasil penilaian dan evaluasi sebagai berikut:

\section{Tabel 17. Statistik deskriptif indikator 9}




\begin{tabular}{|c|c|c|c|c|}
\hline Indikator & Mean & SD & Min & Max \\
\hline PI & 2.881 & 0.512 & 2 & 4 \\
\hline
\end{tabular}

Pada tabel 17 diperoleh rata-rata kemampuan pada indikator 9 rata-rata nilai sebesar 2.881 dengan standar deviasi sebesar 0.512. Besarnya kemampuan dapat digambarkan sebagai berikut:

Gambar 9. Diagram kemampuan guru pada indikator 9

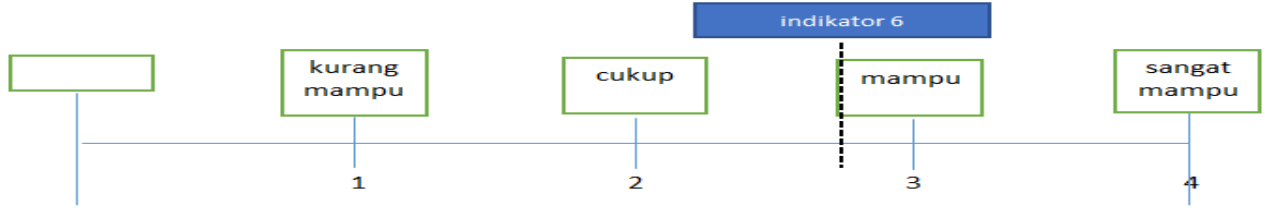

Hasil intepretasi data memanfaatkan hasil penilaiandan evaluasi untuk kepentingan pembelajaran responden menjawab tidak paham/tidak sesuai sebanyak (0.1\%), yang menjawab kurang paham/kurang sesuai sebanyak (25.1\%), menjawab paham/sesuai sebanyak (61.2\%), dan yang menjawab sangat paham/sangat sesuai sebanyak (13.5\%).

Tabel 18. Distribusi frekuensi pada indikator 9

\begin{tabular}{|c|l|r|r|}
\hline No & \multicolumn{1}{|c|}{ Kategori } & Frekuensi & \multicolumn{1}{|c|}{ Persentase } \\
\hline 1 & tidak paham/tidak sesuai & 1 & 0.1 \\
2 & kurang paham/kurang sesuai & 173 & 25.1 \\
3 & paham/sesuai & 421 & 61.2 \\
4 & sangat paham/sangat sesuai & 93 & 13.5 \\
\hline \multicolumn{2}{|c|}{ Total } & 688 & 100 \\
\hline
\end{tabular}

Hasil penelitian mengenai aspek memanfaatkan hasil penilaian dan evaluasi untuk kepentingan pembelajaran dikategorikan mampu. Sebagian responden menjawab paham/sesuai.

\section{J. Melakukan Tindakan Reflektif}

Hasil penelitian menunjukkan untuk indikator mengenai tindakan reflektif sebagai berikut:

Tabel 19. Statistik deskriptif indikator 10 


\begin{tabular}{|c|c|c|c|c|}
\hline Indikator & Mean & SD & Min & Max \\
\hline PJ & 2.906 & 0.485 & 1.67 & 4 \\
\hline
\end{tabular}

Pada tabel 19 rata-rata nilai sebesar 2.906 dengan standar deviasi sebesar 0.485. Besarnya kemampuan digambarkan sebagai berikut:

Gambar 10. Diagram kemampuan guru pada indikator 10

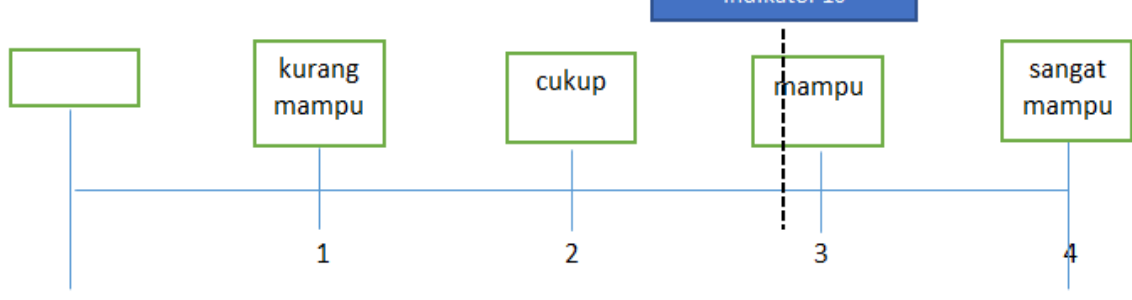

Hasil intepretasi data responden menjawab tidak paham/tidak sesuai sebanyak (0.2\%), yang menjawab kurang paham/kurang sesuai sebanyak (21.3\%), untuk menjawab paham/sesuai sebanyak (66.2\%), dan yang menjawab sangat paham/sangat sesuai sebanyak (12.3\%).

Tabel 20. Distribusi frekuensi pada indikator 10

\begin{tabular}{|c|l|r|r|}
\hline No & \multicolumn{1}{|c|}{ Kategori } & Frekuensi & \multicolumn{1}{|c|}{ Persentase } \\
\hline 1 & Tidak paham/tidak sesuai & 2 & 0.2 \\
2 & Kurang paham/kurang sesuai & 220 & 21.3 \\
3 & Paham/sesuai & 683 & 66.2 \\
4 & Sangat paham/sangat sesuai & 127 & 12.3 \\
\hline \multicolumn{2}{|c|}{ Total } & 1032 & 100 \\
\hline
\end{tabular}

Hasil dari penelitian menunjukkan bahwa mengenai aspek dalam melakukan tindakan reflektif dikategorikan baik. Sebagian besar responden menjawab paham/sesuai.

\section{SIMPULAN}

Secara kesimpulan hasil penelitian kemampuan pedagogik pada indikator: a) Memahami karateristik peserta didik dari aspek fisik, moral, spiritual, sosial, kultural emosional, dan intelektual dikategorikan baik; b) Menguasai Teori 
Belajar Dan Prinsip-Prinsip Pembelajaran dikategorikan baik; c) Mengembangkan kurikulum terkait mata pelajaran yang diampu dikategorikan baik; d) Menyelenggarakan pembelajaran yang mendidik dikategorikan baik; e) Memanfaatkan teknologi informasi dan komunikasi dikategorikan kurang mampu; f) Mengembangkan peserta didik untuk mengaktualisasikan berbagai potensi yang dimilikinyadikategorikan baik; g) Berkomunikasi secara efektif, empatik, dan santun dikategorikan baik; h) Menyelenggarakan penilaian dan evaluasi proses hasil belajar; i) Memanfaatkan hasil penilaian dan evaluasi dikategorikan baik; j) Melakukan tindakan reflektif dikategorikan baik.

\section{DAFTAR PUSTAKA}

Abdurrahman, Mulyono. 2012. Pendidikan Bagi Anak Berkesulitan Belajar. Jakarta : Rineka Cipta.

Agusti dan Pertiwi. 2013. Pengaruh Kompetensi, Independensi dan Profesionalisme Terhadap Kualitas Audit. Jurnal Ekonomi. Vol. 21 No. 3. Pekanbaru.

Dantes, N. 2012. Metode Penelitian. Yogyakarta: CV. Andi Offset.

Fitri, I. (2015). Kompetensi Pedagogik Guru Dalam Mengelola Pembelajaran IPA Di SD dan MI. FENOMENA, 17-28.

Kemendikbud. 2012. Pengembangan Kurikulum 2013. Kementerian Pendidikan dan Kebudayaan. Jakarta.

Kemendikbud. 2013a. Kerangka Dasar dan Struktur Kurikulum 2013. Kementerian Pendidikan dan Kebudayaan. Jakarta.

Muhamad, R. K., Amram, R., \& H. Asep, M. (2016). Kompetensi Pedagogik dan Profesional Guru Sekolah Dasar Yang Tersertifikasi Pada Pembelajaran Sains. Jurnal Sains dan Teknologi, 85-94.

Mulyasa, E. 2013. Standar Kompetensi Dan Sertifikasi Guru. Bandung: PT. Remaja Rosda Karya.

Munandar, S.C. Utami. 2012. Pengembangan Kreativitas Anak Berbakat. Rineka Cipta. Jakarta. 
SOSIAL HORIZON: Jurnal Pendidikan Sosial, Vol. 5, No. 1, Juni 2018

Nani, N. (2015). Kompetensi Pedagogik Guru SMP Dalam Melaksanakan Kurikulum 2013 Pada Rumpun Mata Pelajaran Pendidikan Normatif. Jurnal Ilmiah Cisoc, 1-10.

Neneng, A. (2014). Analisis Kemampuan Pedagogik dan Self Confidence Calon Guru Matematika Dalam Menghadapi Praktek Pengalaman Lapangan. Jurnal Euclid, 55-59.

Undang-Undang Republik Indonesia Nomor 20 Tahun 2003 tentang Sistem Pendidikan Nasional. 2003. Jakarta: Kementrian Pendidikan Nasional RI. 